\title{
A new bathyal amphipod from the Bay of Biscay: Carangolia barnardi sp. nov. (Gammaridea: Urothoidae)
}

\author{
D. Jaume* and J.-C. Sorbe ${ }^{\dagger}$ \\ *Instituto Mediterráneo de Estudios Avanzados (CSIC-UIB), c/ Miquel Marquès 21, 07190 Esporles (Illes Balears), \\ Spain. E-mail: vieadjl@clust.uib.es. ${ }^{\dagger}$ Laboratoire d’Océanographie Biologique, UMR 5805 (GNRS/UB1), \\ 2 rue Jolyet, 33120 Arcachon, France
}

\begin{abstract}
A new species of the cold-temperate austral amphipod genus Carangolia (Gammaridea: Urothoidae) is described from bathyal depths of the Bay of Biscay (north-east Atlantic). It was occasionally sampled in the south-eastern part of the Bay with sledges towed over muddy bottoms between 522 and $924 \mathrm{~m}$ water depth. This depth range falls mainly below the mud-line where the proportion of organic carbon increases in response to the deposition of silts and/or clay sediment. Most specimens were sampled by the lower net of the sledges, indicating a close association with the bottom. Abundance was relatively low, ranging between 0.18 and 4.90 ind $100 \mathrm{~m}^{-2}$, latter recorded below $700 \mathrm{~m}$ depth. The unusual massive appearance of Carangolia mandibles and its preference for bathyal foraminiferal oozes suggest that it is a specialized foraminifer consumer. The antitropical distribution pattern currently displayed by the genus could be an artefact due to equatorial submergence.
\end{abstract}

\section{INTRODUCTION}

Urothoids are marine gammaridean amphipods of fossorial habits, which are very diverse in shallow habitats but scarce in the deep sea (see Barnard \& Karaman, 1991). In the south-eastern part of the Bay of Biscay (Atlantic Ocean), a long-term study of the bathyal suprabenthic communities has generated detailed knowledge of both the composition and ecology of the deep peracarid fauna of the area (Elizalde et al., 1993; Elizalde, 1994; Sorbe \& Weber, 1995; Dauvin \& Sorbe, 1995; Dauvin et al., 1995; Sorbe, 1999). In these communities, urothoids represented $3.6 \%$ of the total gammaridean fauna and $2.8 \%$ of the total amphipod species gathered between 346 and $1098 \mathrm{~m}$ depth (see Dauvin \& Sorbe, 1995). Within this depth range, three urothoid species were recorded, viz Urothoe elegans (Bate, 1856), an as yet undescribed, blind Urothoe species, and a small puliciform species cited as Carangolia sp. in previous reports (Elizalde et al., 1993; Sorbe \& Weber, 1995; Dauvin \& Sorbe, 1995).

In this paper, the small puliciform urothoid is described as a new species and observations on its depth range, abundance and ecology in the south-east Bay of Biscay are presented. The worldwide distribution pattern of the genus Carangolia Barnard, 1961 is discussed.

\section{MATERIALS AND METHODS}

Material was collected on eight occasions (see Table 1) on the upper slope of south-east Bay of Biscay with two sled types, each equipped with superimposed nets (mesh size $=0.5 \mathrm{~mm}$; N1, N4, lowermost, uppermost nets respectively) and with an automatic opening-closing mechanism acting by contact with the sea-floor: the 'Arcachon' sled, that samples the $0-50$ and $50-100 \mathrm{~cm}$ near-bottom water layers (see Sorbe, 1983), and the
'Roscoff' sled, that simultaneously samples the four water layers $10-40,45-75,80-110$ and $115-145 \mathrm{~cm}$ above the bottom (see Dauvin et al., 1995). These gears were towed at $1-2 \mathrm{kn}$ over the bottom.

Specimens were stained using chlorazol black B, following the procedure described in Wagner (1994). Drawings were prepared using a camera lucida on an Olympus BH-2 microscope equipped with Nomarski differential interference contrast. Terms used in descriptions follow Lincoln (1979). Body measurements were derived from the sum of the maximum dorsal somite dimensions. Appendages preserved on permanent slides were mounted in lactophenol and the coverslips sealed with nail varnish. Material is deposited in the crustacean collections of the Muséum National d'Histoire Naturelle, Paris (MNHN).

\section{SYSTEMATICS}

Order AMPHIPODA Latreille, 1816

Suborder GAMMARIDEA Latreille, 1803

Family UROTHOIDAE Bousfield, 1978

Genus Carangolia Barnard, 1961

Carangolia barnardi sp. nov.

(Figures 1-6)

Carangolia sp.: Elizalde et al., 1993; Sorbe \& Weber, 1995; Dauvin \& Sorbe, 1995.

\section{Type material}

(South-east Bay of Biscay, north-east Atlantic).

Holotype: adult female (oostegites developed) $2.69 \mathrm{~mm}$, completely dissected and mounted on 12 slides. (OXYBENT VIII, TS05-R, N4; coordinates: $43^{\circ} 49.34^{\prime} \mathrm{N}$ $02^{\circ} 02.74^{\prime} \mathrm{W}$; water depth: $550 \mathrm{~m}$ ) [MNHN-Am5129]. Collected byJ.-C. Sorbe, 19 April 1999. 
Table 1. Sampling data and diurnal abundance of Carangolia barnardi sp. nov. collected during different sampling cruises on the upper slope of south-east Bay of Biscay.

\begin{tabular}{|c|c|c|c|c|c|c|c|c|c|}
\hline \multirow[b]{2}{*}{ Cruise } & \multirow{2}{*}{$\begin{array}{l}\text { Haul } \\
\text { Code }^{\mathrm{a}}\end{array}$} & \multirow{2}{*}{$\begin{array}{l}\text { Date } \\
\mathrm{d} / \mathrm{m} / \mathrm{y}\end{array}$} & \multirow{2}{*}{$\begin{array}{l}\text { Time }^{\mathrm{b}} \\
\mathrm{h}: \min \end{array}$} & \multicolumn{2}{|c|}{ Position $^{\mathrm{b}}$} & \multirow{2}{*}{$\begin{array}{l}\text { Depth }^{\mathrm{c}} \\
\text { (m) }\end{array}$} & \multirow{2}{*}{$\begin{array}{l}\text { Water layer }{ }^{\mathrm{d}} \\
\qquad(\mathrm{m})\end{array}$} & \multicolumn{2}{|c|}{ Abundance ${ }^{\mathrm{e}}$} \\
\hline & & & & North & West & & & $\mathrm{N}$ & $\mathrm{D}$ \\
\hline \multirow[t]{2}{*}{ ECOFER I } & TS01-R & $01 / 07 / 89$ & $13: 34$ & $44^{\circ} 35.57^{\prime}$ & $02^{\circ} 11.21^{\prime}$ & $523-522$ & $0.10-0.40$ & 2 & 0.38 \\
\hline & TS02-R & $01 / 07 / 89$ & $15: 36$ & $44^{\circ} 36.21^{\prime}$ & $02^{\circ} 12.84^{\prime}$ & $714-708$ & $0.10-0.40$ & 1 & 0.27 \\
\hline \multirow[t]{3}{*}{ ESSAIS II } & TS09-R & $18 / 05 / 89$ & $16: 31$ & $44^{\circ} 33.22^{\prime}$ & $02^{\circ} 12.48^{\prime}$ & $740-754$ & $0.10-0.40$ & 1 & 0.27 \\
\hline & TS10-R & $18 / 05 / 89$ & $13: 36$ & $44^{\circ} 33.10^{\prime}$ & $02^{\circ} 13.13^{\prime}$ & $791-790$ & $0.10-0.40$ & 7 & 2.13 \\
\hline & TS11-R & $03 / 07 / 90$ & $15: 00$ & $44^{\circ} 32.89^{\prime}$ & $02^{\circ} 14.24^{\prime}$ & $923-924$ & $0.10-0.40$ & 4 & 1.43 \\
\hline CAPBRETON 90* & TS16-A & $03 / 07 / 90$ & $18: 13$ & $43^{\circ} 38.41^{\prime}$ & $02^{\circ} 15.58^{\prime}$ & $727-727$ & $0-0.50$ & 2 & 2.53 \\
\hline ECOMARGE 93 & TS08-A & $23 / 06 / 93$ & $20: 06$ & $44^{\circ} 34.57^{\prime}$ & $02^{\circ} 12.60^{\prime}$ & $740-746$ & $0-0.50$ & 5 & 4.90 \\
\hline OXYBENT VIII* & TS05-R & $19 / 04 / 99$ & $13: 28$ & $43^{\circ} 49.34^{\prime}$ & $02^{\circ} 02.74^{\prime}$ & $550-550$ & $1.15-1.45$ & 1 & 0.18 \\
\hline
\end{tabular}

a, A, 'Arcachon' sled (see Sorbe, 1983); R, 'Roscoff' sled (see Dauvin et al., 1995); ', hour and position of the ship at the beginning of the haul on the bottom; ' , depth recorded below the ship at the beginning and at the end of the haul on the bottom; ${ }^{\mathrm{d}}$, water layers sampled by the sleds above the bottom; ${ }^{\text {e }}, \mathrm{N}$, number of individuals collected; D, density (ind $100 \mathrm{~m}^{-2}$ ). *, unpublished data.

Paratype: adult male (penile papillae developed) $3.88 \mathrm{~mm}$ partially dissected, with both first antennae, maxillipeds, epimeral plates, pleopods, and second antenna and second gnathopod mounted on three slides; rest as five pieces preserved in 70\% ethanol. (ECOMARGE 93, TS08-A, N1; $44^{\circ} 34.57^{\prime} 02^{\circ} 12.60^{\prime} \mathrm{W}$; water depth: 740-746 m] [MNHNAm5130]. Collected by J.-C. Sorbe, 23 June 1993. Twentyone additional specimens in J.-C. Sorbe collection.

\section{Comparative material examined}

Carangolia cornuta Bellan-Santini \& Ledoyer, 1986. Holotype: female completely dissected on single slide [Museo Givico di Storia Naturale di Verona, slide no. 3276]. RV 'Marion Dufresne' Cruise MD08 to Marion and Prince Edward Islands, Station 17BB97 (Marion Island; 46 52'5S 37 53'5E). Collected 25 March 1976 with Okean grab on muddy sand, $110 \mathrm{~m}$ depth.

\section{Diagnosis}

Carangolia with well developed pointed process on posterolateral corner of head. Coxal plate 1 with anterior and posterior margins subparallel, distal margin straight. Coxal plate 7 pointed. Basis of pereopod 6 slender, not oblong. Dactylus of pereopod 5 elongate (more than 12 times longer than wide). Telson devoid of spines.

\section{Description of adult female}

Body unpigmented, apparently eyeless, short, dorsoventrally depressed (Figure 1A shows male body, identical with that of female). Head (Figure 1B) with rostrum (Figure 2A) obsolete; lateral lobe and post-antennal sinus both hardly developed; posterolateral corner with acute curved process directed forwards. Surface of body somites smooth.

First antenna (Figure 2A) short, with peduncle articles of similar length. Flagellum 3-articulate, two distal articles each bearing single simple aesthetasc; distal article with thick, modified setal element with array of filiform processes at tip (Figure 2C). Accessory flagellum (Figure 2B) reduced to tiny, single article crowned with modified setal element. Calceoli apparently absent.

Second antenna (Figure 2D) implanted widely separate from insertion of first antenna laterally, shorter than it. Peduncle articles 4-5 provided with slender spines with sensillum as figured. Flagellum reduced to two articles. Calceoli absent.

Upper lip (Figure 1D shows male upper lip, identical with that of female) frontal aspect roughly triangular, anterior margin hairless; epistome indistinct. Lower lip (Figure 1E shows male lower lip, identical with that of female) with hairless, rounded inner lobes not reaching tip of outer lobes; outer lobes finely setulose distally.

Mandibles (Figures 1B \& 3A) symmetrical, massive, each with terminal smooth, reniform sclerotized grinding plate; homology of grinding plate (i.e. whether representing incisor or molar) unresolved. No trace of lacinia mobilis or spine row. Palp long and slender, 3-articulate; proximal article short, unarmed; second elongate, slightly curved, with single seta about two-thirds of distance along margin; third slightly shorter than preceding article, with three unequal terminal setae.

Maxilla 1 (Figure 4A) with slender rectangular inner plate, with four plumose setae along distal margin. Outer plate with eight unequal spines on distal margin: two simple, four bifid, and two dentate. Palp not surpassing outer plate distally, 2-articulate, both articles of similar length; distal with three plumose setae and tiny denticle distally.

Maxilla 2 (Figure 4B) with both plates of similar length. Outer plate subrectangular, with row of five plumose setae plus one stout unipectinate seta distally, and subdistal row of five stout unipectinate setae plus two innermost plumose setae. Inner plate digitiform, with 11 plumose setae distally and patch of setules along medial margin; most proximal pinnule on each seta stouter than rest.

Maxilliped (Figure 4C) with plates of similar length. Inner plate rectangular, with subdistal row of five pinnate setae on posterior (=ventral) surface, three smooth clavate spines partially embedded into plate distally, and two smooth and one pinnate setae subdistally on anterior (=dorsal) surface (Figure 4D). Outer plate with medial margin straight, lateral margin evenly rounded; armature consisting of submarginal row of six plumose setae on posterior surface, and marginal row of six smooth clavate spines and single distalmost stout pinnate seta. Palp 

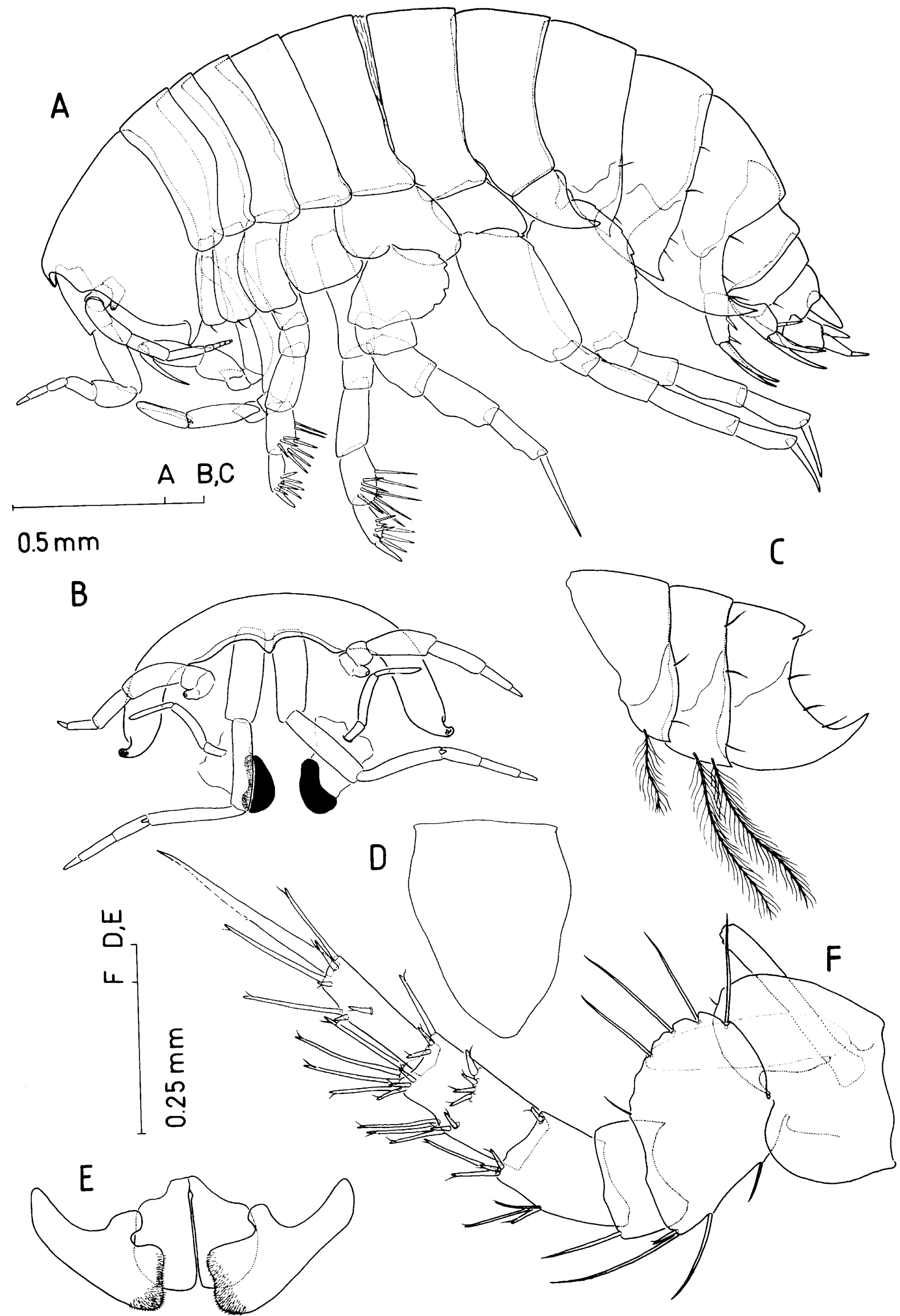

Figure 1. Carangolia barnardi sp. nov. (A) Male body, lateral aspect; (B) female head, anterior (upper lip omitted); (C) female pleonites, lateral; (D) male upper lip, anterior; (E) male lower lip, anterior; (F) female right fifth pereopod with attached coxal gill and oostegite. 


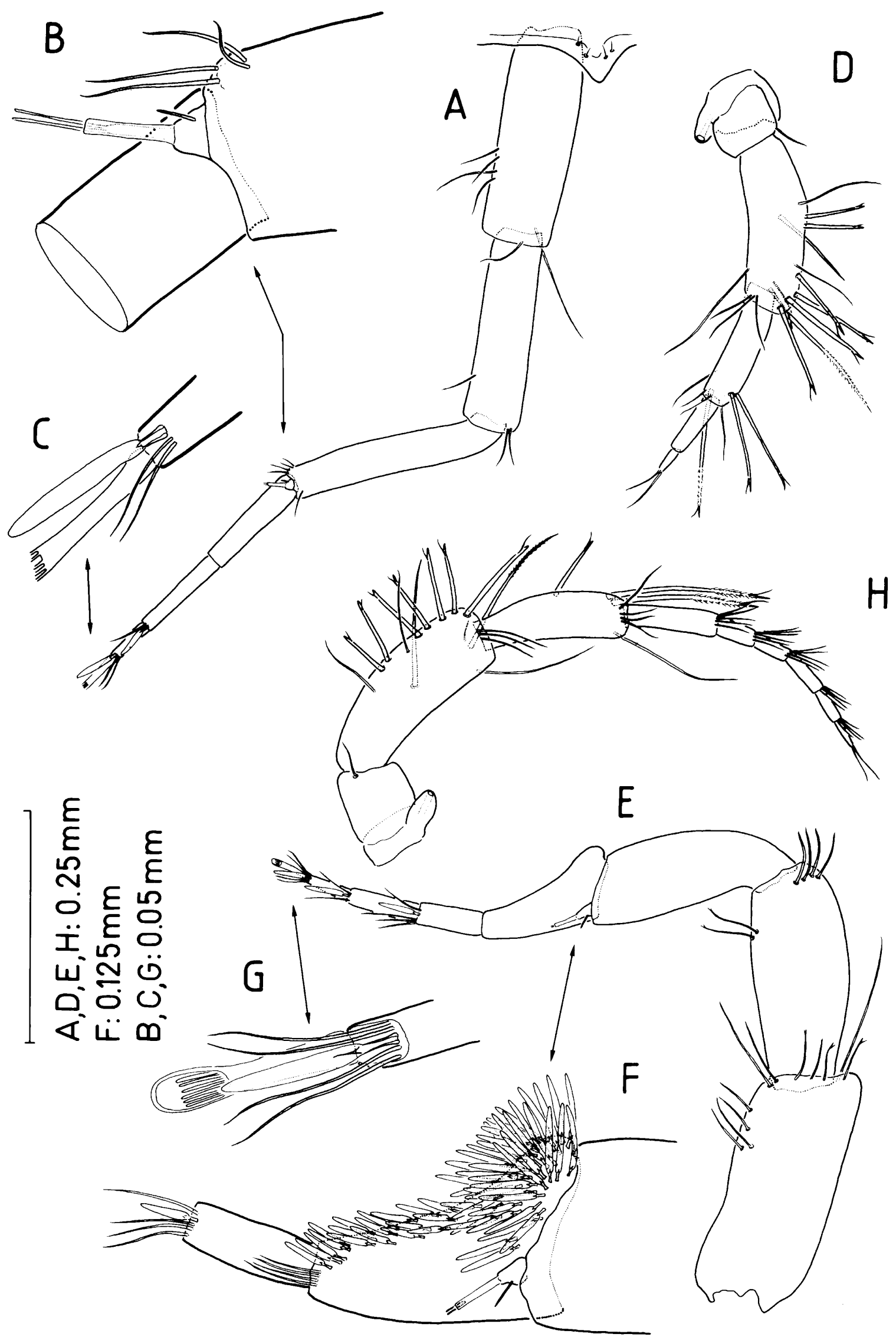

Figure 2. Carangolia barnardi sp. nov. (A) Female rostrum and right first antenna, latter in anterior (=dorsal) aspect; (B) detail of accessory flagellum; (G) detail of tip of main flagellum with ordinary and modified setae; (D) female right second antenna, lateral; (E) male left first antenna, anterior (ornamentation on proximal article of flagellum omitted); (F) detail of two proximal articles of flagellum and of accessory flagellum; $(\mathrm{G})$ detail of tip of flagellum with ordinary and modified setae; $(\mathrm{H})$ male second antenna, lateral. 


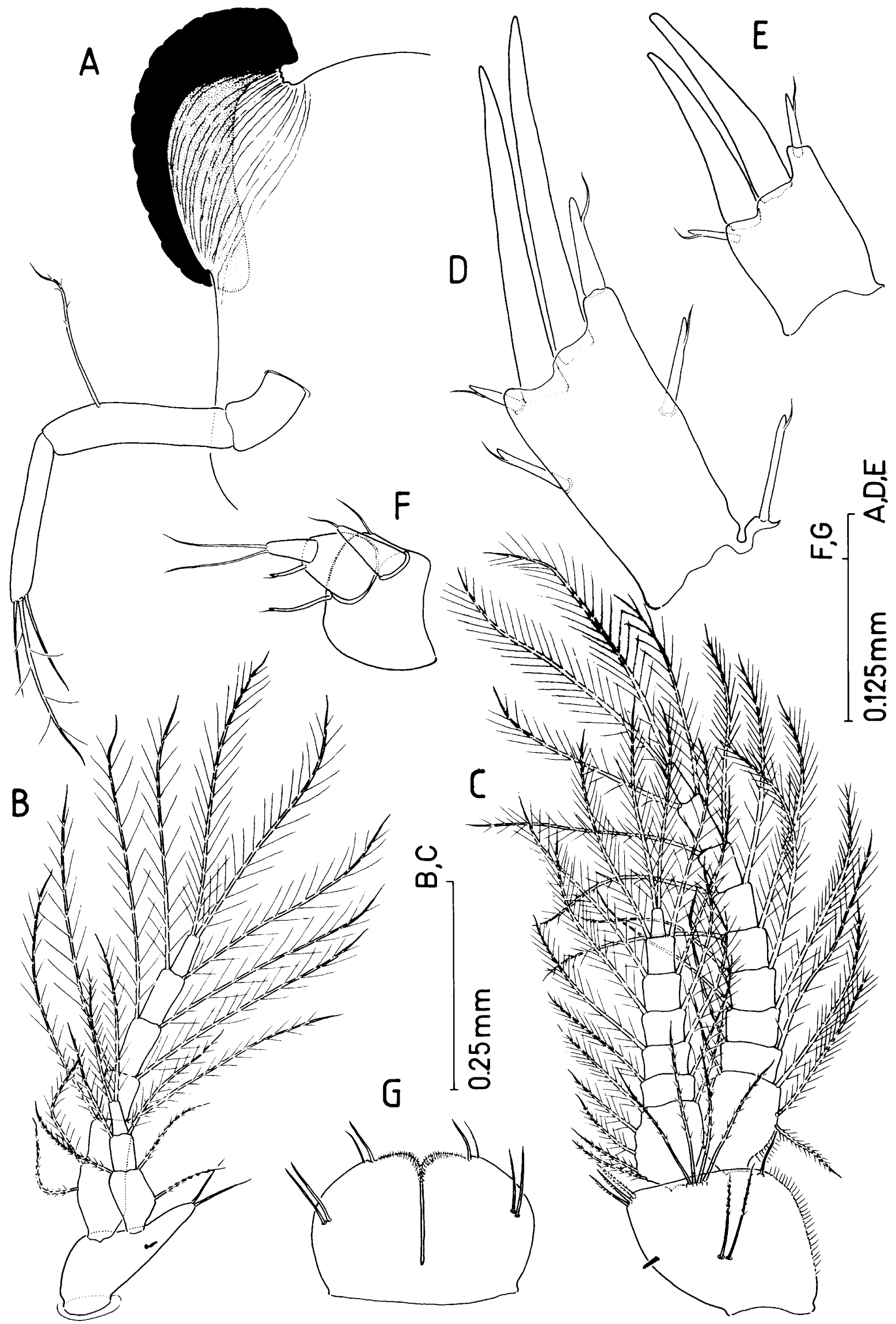

Figure 3. Carangolia barnardi sp. nov. (A) Female right mandible, lateral aspect; (B) female left pleopod 1, anterior; (C) male right pleopod 1, anterior; (D) female first uropod, anterior (=ventral); (E) female second uropod, anterior $(=$ ventral); (F) female third uropod, posterior (=dorsal); $(\mathrm{G})$ female telson, posterior (=dorsal). 


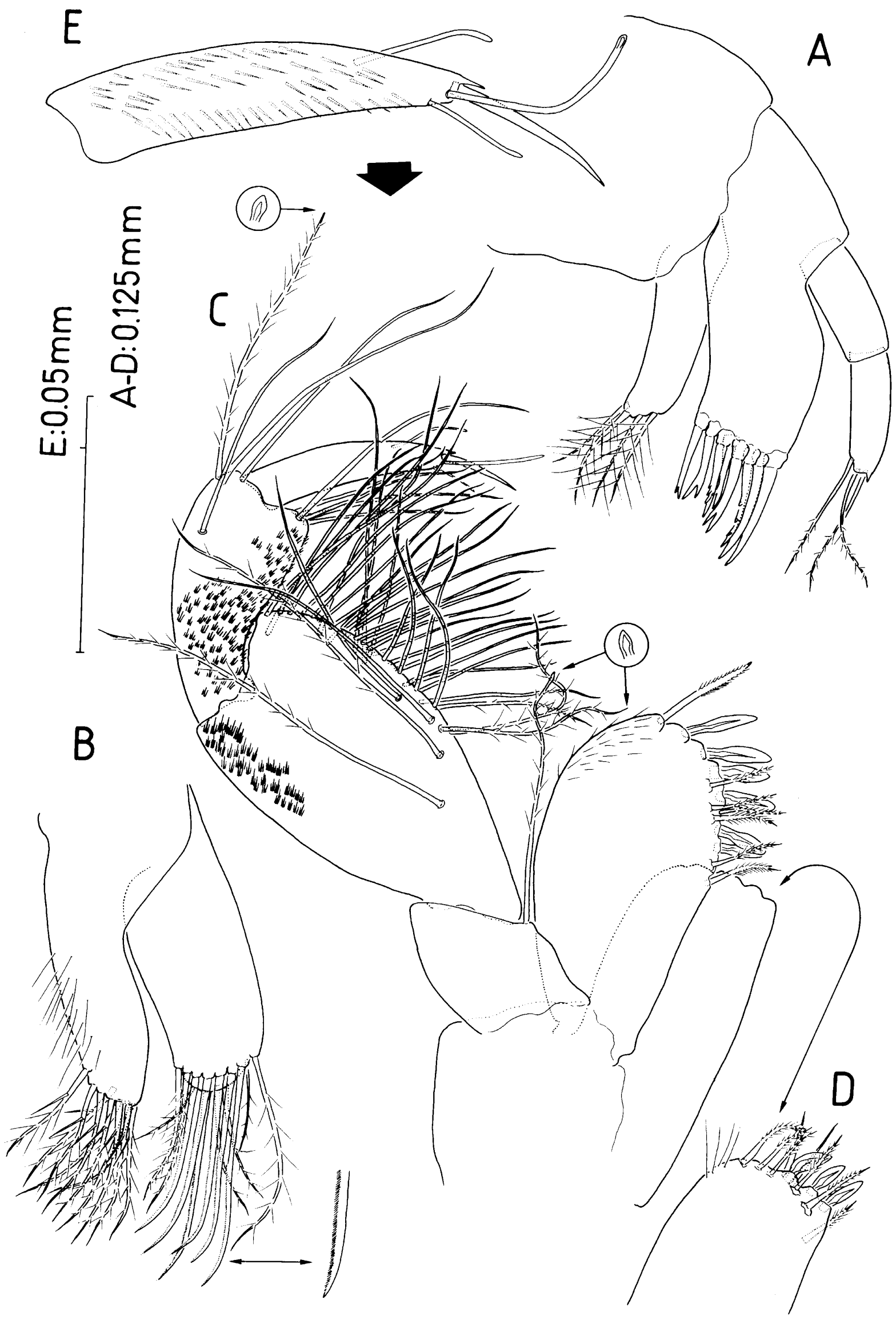

Figure 4. Carangolia barnardi sp. nov., adult female. (A) First maxilla, posterior (=ventral) aspect; (B) second maxilla; (C) maxilliped, posterior (=ventral) (inner plate, and fourth palp article and nail outlined); (D) detail of armature of inner plate of maxilliped, posterior (=ventral); (E) detail of ornamentation of fourth article and nail of maxillipedal palp, posterior $(=$ ventral $)$. 


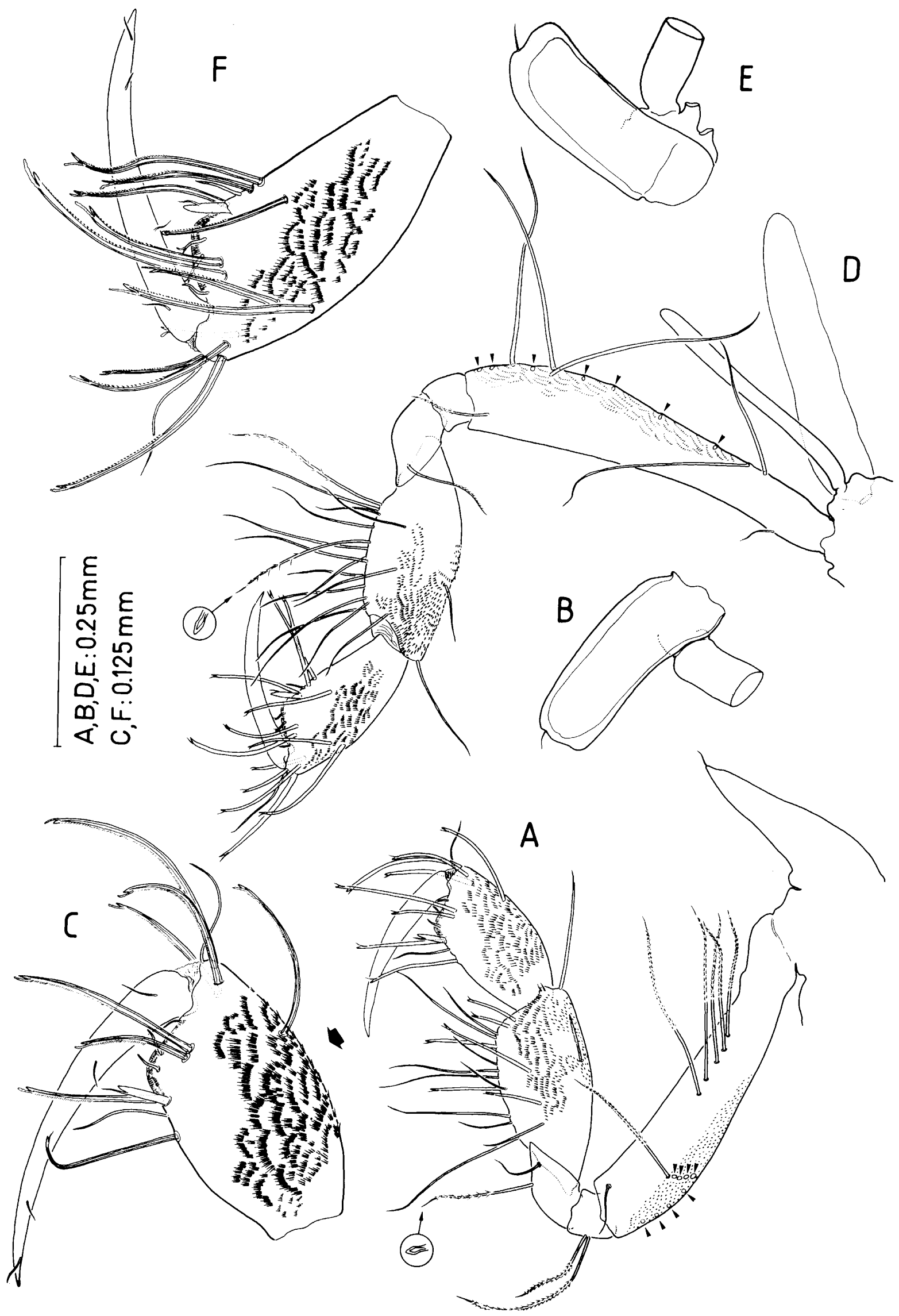

Figure 5. Carangolia barnardi sp. nov., adult female. (A) Right first gnathopod, medial (coxa in sagittal aspect); (B) detail of coxa of left gnathopod 1, lateral; (C) detail of hand of left gnathopod 1, medial; (D) second left gnathopod with attached oostegite and coxal gill, medial (coxa omitted); (E) detail of coxa of latter, lateral; (F) detail of hand of left second gnathopod, medial. Arrowheads on A and B pointing to insertions of accidentally lost setae. 


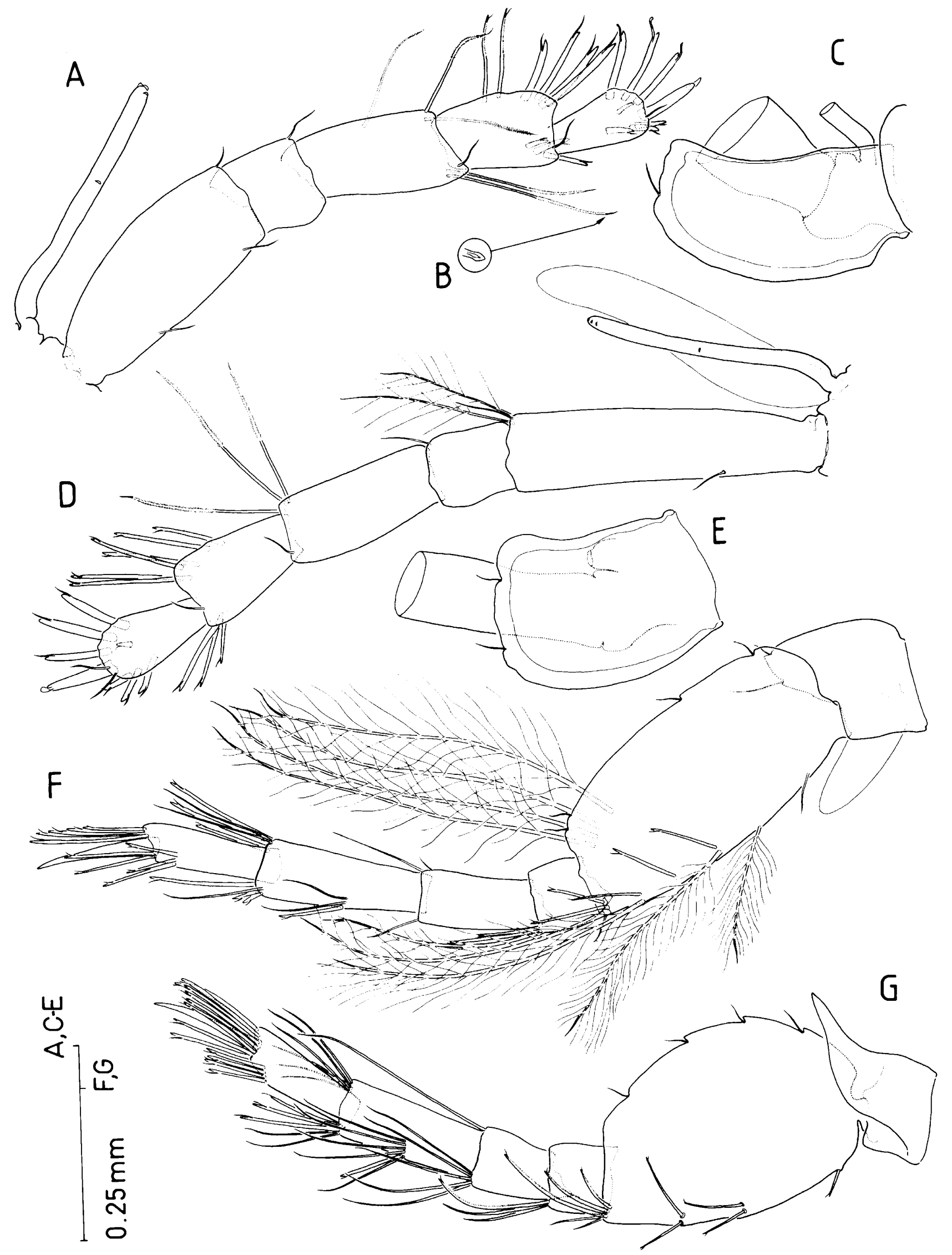

Figure 6. Carangolia barnardi sp. nov., adult female. (A) Right third pereopod with oostegite, medial aspect (coxa and coxal gill omitted); (B) detail of tip of one of setae on third pereopod; $(\mathrm{C})$ coxa of right third pereopod, lateral (insertion of basis and of oostegite outlined, coxal gill omitted); (D) left fourth pereopod with attached oostegite and coxal gill, medial (coxa omitted); (E) coxa of right fourth pereopod, lateral; (F) right sixth pereopod with attached gill, lateral; G, right seventh pereopod, lateral. 
4-articulate; proximal article with single seta distally on inner margin. Second article expanded distomedially, with about 45 setae; distolateral surface finely spinulate. Third article with distomedial corner expanded into rounded lobe carrying five setae; distolateral corner with three setae; surface with spinulation distributed as figured. Fourth article (Figure 4E) slender, falcate, slightly shorter than previous article, with anterior surface covered with sparsely distributed, long spinules; three short smooth setae positioned as figured. Distal nail long and slender, spine-like. Setae on palp articles with expanded, spoon-shaped tips.

Coxal plates 1-4 (Figure 1A) with roughly similar aspect: subparallel margins, anterior margin convex, posterior margin shallowly excavate, distal margin straight. Plates 1 (Figure 5B) and 2 (Figure 5E) of similar length, but former more slender (2.9 times longer than wide versus 2.3 times for second plate); both plates bearing single seta on distal margin. Plate 3 (Figure 6C) longer than preceding plates, 1.9 times longer than wide, with single seta on distal margin. Plate 4 (Figure 6E) shorter and wider than preceding plate (1.4 times as long as wide), with two setae on distal margin.

Coxal plate 5 (Figure 1F) bilobed, with anterior margin overlapping posterior margin of coxal plate 4; posterodistal angle strongly overhanging. Coxal plate 6 (Figure $6 \mathrm{~F}$ ) with anterior margin straight; posterodistal angle strongly overhanging, with two notches each harbouring short seta. Coxal plate 7 (Figure 6G) with distal margin tapering, forming strongly pointed process directed posteriorly.

Coxal gills on gnathopod 2 (Figure 5D) and on pereopods 3 to 6 (Figures $1 \mathrm{~F} \& 6 \mathrm{D}, \mathrm{F}$ ) simple, sac-like, unstalked. Oostegites present on gnathopod 2 (Figure 5D) and pereopods 3 to 5 (Figures $1 \mathrm{~F} \& 6 \mathrm{~A}, \mathrm{D}$ ), linear, apparently provided with 3-4 terminal setae (setae lost in single female available).

Gnathopod 1 (Figure 5A) strongly subchelate, slender. Basis about 4.7 times longer than wide, with medial surface bearing submarginal row of five long setae proximally near anterior margin, and transverse row of five setae at about three-quarters of distance along posterior margin; posterior margin of article with row of four setae in distal quarter. Carpus 2.3 times longer than wide, posterior margin slightly expanded, bearing numerous stiff setae with apical sensillum. Propodus (Figure 5C) oval, twice as long as wide, shorter than carpus, with palm angle positioned at $65 \%$ of total length of article. Single spine with sensillum and stiff seta with apical sensillum on palmar angle. Palm convex, covered with densely-set short spinules. Dactylus slender, longer than propodus. Surface of basis, carpus and propodus with densely-set short spinules as figured.

Gnathopod 2 (Figure 5D) similar to previous limb except for some additional stiff setae with apical sensillum on medial surface of propodus (Figure 5F), and far more elongate basis. Latter differing also in armature: long setae placed only along posterior margin of article. Setae on articles of both gnathopods with expanded, spoonshaped tips.

Pereopods 3-4 (Figure 6A,D) with characteristic spinose, club-shaped 'haustoriid' aspect, differing from each other in relative length of basis (2.3 times longer than wide in $\mathrm{P} 3$ vs 4.2 times in $\mathrm{P} 4$ ), and relative thickness of spines with sensillum on medial margin of carpus (spines stouter in P3). Setae on both pereopods with expanded, spoon-shaped tips (Figure 6B).

Pereopod 5 (Figure $1 \mathrm{~F}$ ) basis broadened, about as long as wide, with posterior margin strongly convex, bearing four notches, each with stiff seta; posterodistal lobe wanting. Dactylus long and slender (12.3 times longer than wide), clearly longer (1.5 times longer) than preceding article.

Pereopod 6 (Figure 6F) basis slender, twice as long as wide, with slightly convex margins, posterodistal lobe wanting; long plumose setae along anterior margin, plus submarginal row of similar setae on medial surface of article near posterodistal angle. Posterior margin of basis with two shallow notches proximally, each bearing slender seta.

Pereopod 7 (Figure 6G) with basis 1.4 times longer than wide, with strongly convex posterior margin bearing four notches, each with slender seta; posterodistal lobe wanting.

Epimeral plates (Figure 1C) increasing progressively in size from 1 to 3 , with ventral margins evenly rounded and with pointed posterodistal angles. Ventral margin of plates 1-2 with one and two long, plumose setae respectively. Plate 3 with posterodistal corner strongly produced into falcate process. Pleopods 1-3 (Figure 3B) similar, inner ramus with three articles, outer ramus 5-articulate. Peduncle with distomedial margin produced into pointed process crowned with two setae; length of process diminishing from pleopod 1 to 3.

Uropods decreasing progressively in length from 1 to 3 , biramous. Uropod 1 (Figure 3D) with both rami unarmed, 1-articulate, styliform, of equal length and longer than peduncle. Peduncle rectangular in anterior aspect, about 1.9 times longer than wide, with produced distomedial corner; two robust spines with sensillum on each side of article as figured; more slender spine with sensillum inserted medially near articulation of article with sternite. Uropod 2 (Figure 3E) similar to uropod 1, but with peduncle subquadrate and armature reduced to single terminal spine with sensillum on each side. Uropod 3 (Figure $3 \mathrm{~F}$ ) short and compact, with peduncle inflated, wider than long, bearing single seta on distomedial corner and slender spine with sensillum about midway along distal margin; both rami inserted on posterior (=dorsal) surface of peduncle close to distomedial corner; inner ramus 1-articulate, shorter than peduncle, triangular with single seta on tip; outer ramus 2-articulate, conical, proximal article with slender spine with sensillum on distolateral corner, distal article with two setae on tip.

Telson (Figure 3G) free and deeply cleft $(74 \%$ of telson length), wider than long. Lobes with pilose inner part of distal margin, and with outer margin evenly rounded; each with pair of short unequal setae subdistally on outer margin and pair of submarginal setae on middorsal surface.

\section{Description of adult male}

Similar to female except for first antenna and pleopods. Significance of larger body size and higher number of articles in flagellum of both antennae (Figure $2 \mathrm{H}$ ), as sexually dimorphic characters, unconfirmed. 
First antenna (Figure 2E) with peduncle articles stouter than in female. Flagellum 4-articulate; first article with medial margin expanded proximally into lobe covered by tightly set, simple aesthetascs (Figure 2F). Single simple aesthetasc on each of three distal flagellum articles. Distalmost article with thick, modified setal element (Figure 2G). Calceoli apparently absent.

Pleopods (Figure 3C) with both rami comprising higher number of articles than in female (outer ramus 9-articulate, inner ramus 7-articulate). Peduncle differing from female in hardly produced distomedial corner, presence of three sets of setae on anterior surface of article, and in setulose outer margin.

\section{Etymology}

Species dedicated to the late J. Laurens Barnard, in recognition to his outstanding contribution to amphipod taxonomy.

\section{Remarks}

To date the genus Carangolia was composed of only three species from cold-temperate austral latitudes, viz C. puliciformis Barnard, 1961, C. mandibularis Barnard, 1961, and C. cornuta Bellan-Santini \& Ledoyer, 1986. The new species from the Bay of Biscay can be easily distinguished from the two species described by Barnard (1961, 1962) by the pointed (versus blunt) aspect of coxal plate 7 .

Based on the degree of development of the pointed process on the posterolateral corner of the head and the morphology of the coxal plate 7 , the new species seems to be most closely related to $C$. cornuta (coxa 7 not described by Bellan-Santini \& Ledoyer (1986), but actually showing a backward pointed process, as according to our own observations on the holotype). Nevertheless, there are important differences between both taxa in the morphology of the coxal plate 1 , the relative length of the pereopod 5 dactylus, the shape of pereopod 6 basis, and the telson armature. Coxal plate 1 of the new species has the anterior and posterior margins sub-parallel and the distal margin straight, whereas this plate has the distal margin strongly oblique in C. cornuta (personal observation on the holotype). In addition, the dactylus of the pereopod 5 is longer and more slender in the new species than in C. cornuta, where it is only 6.3-6.9 times longer than wide and only 1.1-1.2 times longer than the propodus. The basis of the sixth pereopod is slender in the new species, whereas oblong in C. cornuta. A fourth diagnostic difference is the telson armature, which is devoid of spines in the new species but carries a stout distal spine on each lobe in C. cornuta, as shown by BellanSantini \& Ledoyer (1986).

\section{DISTRIBUTION AND AUTOECOLOGY}

The genus Carangolia was erected by Barnard (1961) to accommodate two new deep-sea taxa from fairly distant localities in the southern hemisphere: C. puliciformis from the Tasman Sea, sampled on a Globigerina ooze at $610 \mathrm{~m}$ depth; and C. mandibularis (the type species) from the Cape Basin slope (south Atlantic Ocean), sampled at 1861 and $2972 \mathrm{~m}$ on a substratum consisting of 'cream forams' for the deepest station (an erroneous water depth was mentioned in Barnard, 1961 for this station). Later,
Bellan-Santini \& Ledoyer (1986) added a third austral species to the genus, C. cornuta, sampled at $110 \mathrm{~m}$ (muddy sand) and $192 \mathrm{~m}$ (sand) near Marion Island (south-west Indian Ocean).

In the south-eastern part of the Bay of Biscay, the fourth species $C$. barnardi sp. nov. was infrequently sampled with sledges towed over muddy bottoms from the Capbreton Canyon (Kostarrenkala sampling site) and from the adjacent northern open slope (Plateau des Landes sampling site; see Table 1). In this area, 23 specimens have been collected during daytime at depths between 522 and $924 \mathrm{~m}$, i.e. mainly below the mud-line where the proportion of organic carbon increases in response to the deposition of silts and/or clayey sediment (see Etcheber et al., 1999). The uppermost distribution limit of this species is confirmed by its absence in the 11 monthly samples performed at $\sim 400 \mathrm{~m}$ water depth on the southern margin of the Cap Ferret Canyon (see Elizalde, 1994). Its lowermost limit is provisional because few samples were available from deeper than $924 \mathrm{~m}$. However, it was not sampled at $\sim 2400 \mathrm{~m}$ depth within the Cap Ferret Canyon during the ECOFER experiment (J.-C.S., unpublished data). Most of the available specimens $(95.7 \%)$ were sampled by the lower net of the sledges, thus indicating a close association with the bottom, in accord with a fossorial behaviour as indicated for some other urothoid taxa (Enequist, 1949; BellanSantini, 1998). However, one individual (the female selected as holotype) was collected in the $115-145 \mathrm{~cm}$ water layer above the bottom. Abundance values were relatively low, ranging between 0.18 and 4.90 ind $100 \mathrm{~m}^{-2}$, the latter recorded below $700 \mathrm{~m}$ depth.

With the discovery of $C$. barnardi in the Bay of Biscay this genus, apparently restricted to cold-temperate austral latitudes, now displays a typical antitropical (sensu Briggs, 1995) distribution pattern. A trend for species living in higher latitudes to dwell in shallower waters is apparent when comparing the depth and latitudinal ranges of the four species known, which may indicate cold stenothermic and eurybathic habits for the genus. The very incomplete knowledge of the deep-sea benthic communities off the west coast of Africa precludes any decision on whether this apparently antitropical pattern, with a same genus having species on either side of the tropical belt but absent in it, is real, or whether there is a latitudinal continuum of species with the tropical representatives remaining hidden in cold deep waters due to the so-called 'equatorial submergence' (see Ekman, 1953).

The peculiar massive appearance of Carangolia mandibles was recognized by Barnard (1961, 1962), and suggests a specialized diet. The gut contents of C. mandibularis (the holotype collected at $1861 \mathrm{~m}$ depth) consisted of clumps of finely particulate mineral and organic remains plus coccoliths (Barnard, 1962), and does not permit any refinement in the determination of its feeding habits. Such bulky mandibles (massive chitinized incisors) are also known from bathyal oedicerotids belonging to the genus Bathymedon G.O. Sars, 1892 (viz B. longimanus (Boeck, 1871); B. acutifrons Bonnier, 1896; B. longirostris Jaume et al., 1998) and were interpreted as an adaptation for crushing pelagic and benthic foraminifers (Jaume et al., 1998). Moreover, massive mandibles were similarly related to foraminiferivory in some bathyal benthic 
asellote isopods (Svavarsson et al., 1993; Elizalde, 1994; Elizalde et al., 1999). Carangolia species share with these benthic peracarid crustaceans both the mandible structure and the same preference for bathyal foraminifer oozes, suggesting the genus could be also a specialized foraminifer consumer.

This research programme was partly supported by the French CIRMAT-GNRS (oceanographic cruises ESSAIS II, CAPBRETON 90 and OXYBENT VIII) and by the ECOMARGE programme of France-JGOFS (oceanographic cruise ECOFER I and ECOMARGE 93). We are greatly indebted to the crews of the RVs 'Côte d'Aquitaine', 'Côtes de la Manche' and 'Le Noroît' for their helpful assistance at sea, to J.-C. Dauvin for the loan of the 'Roscoff' sled, to I. Frutos for sorting the Capbreton samples, and to D. Bellan-Santini (Station Marine d'Endoume, Marseille) and S. Ruffo (Museo Civico di Storia Naturale di Verona) for useful suggestions and for the loan of the material of Carangolia cornuta. Professor R. Lincoln (The Natural History Museum, London) is acknowledged for advising on the condition of the modified first antenna setae of the new species.

\section{REFERENCES}

Barnard, J.L., 1961. Gammaridean Amphipoda from depths of 400 to 6000 meters. Galathea Report, 5, 23-128.

Barnard, J.L., 1962. South Atlantic abyssal amphipods collected by R/V Vema. In Abyssal Crustacea (ed. M. Ewing), pp. 1-78. New York: Columbia University Press. [Vema Research Series, no. 1.]

Barnard, J.L. \& Karaman, G.S., 1991. The families and genera of marine gammaridean Amphipoda (except marine gammaroids). Parts 1 and 2. Records of the Australian Museum, Supplement 13, 1-866.

Bellan-Santini, D., 1998. Ecology. In The Amphipoda of the Mediterranean, Part 4 (ed. S. Ruffo), pp. 869-893. Monaco: Mémoires de l'Institut Océanographique.

Bellan-Santini, D. \& Ledoyer, M., 1986. Gammariens (Crustacea, Amphipoda) des Iles Marion et Prince Edward. Bollettino del Museo Civico di Storia Naturale di Verona, 13, 349435.

Briggs, J.C., 1995. Global biogeography. Developments in Palaeontology and stratigraphy. Amsterdam: Elsevier.

Dauvin, J.-G. \& Sorbe, J.-C., 1995. Suprabenthic amphipods from the southern margin of the Cap Ferret canyon (Bay of Biscay, north-eastern Atlantic Ocean): abundance and bathymetric distribution. Polskie Archiwum Hydrobiologii, 42, 441-460.

Dauvin, J.-C., Sorbe, J.-C. \& Lorgere, J.C., 1995. Benthic Boundary Layer macrofauna from the upper continental slope and the Cap Ferret canyon (Bay of Biscay). Oceanologica Acta, 18, 113-122.

Ekman, S., 1953. Zoogeography of the sea. London: Sidgwick \& Jackson.
Elizalde, M., 1994. Les communautés suprabenthiques bathyales de la marge sud du canyon du Cap Ferret (Golfe de Gascogne). Thesis $3^{\mathrm{e}}$ cycle, University of Bordeaux, France.

Elizalde, M., Sorbe, J.-C. \& Dauvin, J.-C., 1993. Las comunidades suprabentónicas batiales del golfo de Vizcaya (margen sur del cañón de Cap-Ferret): composición faunística y estructura. Publicaciones Especiales del Instituto Español de Oceanografía, 11, 247-258.

Elizalde, M., Weber, O., Pascual, A., Sorbe, J.-G. \& Etcheber, H., 1999. Benthic response of Munnopsurus atlanticus (Crustacea: Isopoda) to the carbon content of the nearbottom sedimentary environment on the southern margin of the Cap-Ferret Canyon (Bay of Biscay, north-eastern Atlantic Ocean). Deep-Sea Research, 46, 2331-2344.

Elizalde, M., Weber, O. \& Sorbe, J.-C., 1993. Influence des caractères sédimentologiques sur la distribution des crustacés benthiques de la pente atlantique (Golfe de Gascogne; marge sud du Canyon du Cap Ferret). In Actes du IIIe Colloque International 'Océanographie du Golfe de Gascogne', Arcachon, 7-9 April 1992 (ed. J.-C. Sorbe and J.M. Jouanneau), pp. 269-273. Arcachon: University of Bordeaux 1.

Enequist, P., 1949. Studies on the soft-bottom amphipods of the Skaggerak. Zoologiska bidrag frain Uppsala, 28, 297-492.

Etcheber, H., Relexans, J.C., Beliard, M., Weber, O., Buscail, R. \& Heussner, S., 1999. Distribution and quality of sedimentary organic matter on the Aquitanian margin (Bay of Biscay). Deep-Sea Research, 46, 2249-2288.

Jaume, D., Cartes, J.E. \& Sorbe, J.-C., 1998. A new species of Bathymedon Sars, 1892 (Amphipoda: Oedicerotidae) from the western Mediterranean bathyal floor. Scientia Marina, 62, 341356.

Lincoln, R.J., 1979. British marine Amphipoda: Gammaridea. London: British Museum (Natural History).

Sorbe, J.-C., 1983. Description d'un traîneau destiné à l'échantillonnage quantitatif étagé de la faune suprabenthique néritique. Annales de l'Institut Océanographique, Paris, 59, 117-126.

Sorbe, J.-C., 1999. Deep-sea macrofaunal assemblages within the Benthic Boundary Layer of the Cap-Ferret canyon (Bay of Biscay, north-east Atlantic). Deep-Sea Research, 46, 2309-2329.

Sorbe, J.-C. \& Weber, O., 1995. Influence de la profondeur et des sédiments superficiels sur la structure des communautés suprabenthiques bathyales sud-Gascogne. In Actas del IV Coloquio Internacional sobre Oceanografía del Golfo de Vizcaya, Santander, 12-14 April 1994 (ed. O. Cendrero and I. Olaso), pp. 183-194. Santander: Instituto Español de Oceanografía.

Svavarsson, J., Gudmundsson, G. \& Brattegard, T., 1993. Feeding by asellote isopods (Crustacea) on foraminifers (Protozoa) in the deep-sea. Deep-Sea Research, 40, 1225-1239.

Wagner, H.P., 1994. A monographic review of the Thermosbaenacea (Crustacea: Peracarida). A study on their morphology, taxonomy, phylogeny and biogeography. Zoologische Verhandelingen, 291, 1-338.

Submitted 6 Fuly 2000. Accepted 16 November 2000. 